\title{
THE REGULARITIES OF VARIABILITY OF KIMBERLITE COMPOSITIONS IN MULTI-PHASE PIPES.
}

Kostrovitsky S.I.

Institute of Geochemistry, Siberian Branch, USSR Academy of Sciences, Irkutsk, USSR.

The majority of well studied great kimberlite pipes belong to multi-phase formations. About live kimberlite varieties fill such pipes as Mir, Udachnaya-Zapadnaya, Udachnaya-Vostochnaya, Aykhal. The kimberlites of different phases of intrusion form individual independent bodies within pipes. The contact relationships between them dispaly the sequence of their intrusion. It turned out that in a number of observed pipes the inftial phases of intrusions are associated with kimberlites of the massive texture and the final phases relate to autolith-bearing breccias.

The study of petrochemical and microelement compositions showed that kimberlites of seperate phases of intrusion possess a distinct composition feature. As the factor analysis indicates, the main trend of petrochemical variability of kimberlites is due to variations of carbonate and silicate components of rocks. This shows different intensity of superimposed carbonatization and to lesser extent magmatic differentiation. The next distinct trend is derived for multi-phase pipes from the so-called "significant" oxides, which are mostly stable in the secondary processes. The tendency for diminishing $\mathrm{TiO}_{2}, \mathrm{FeO}, \mathrm{K}_{2} \mathrm{O}$ and $\mathrm{P}_{2} \mathrm{O}_{5}$ contents is well defined from initial phases of intrusion towards final ones; kimberlite becomes more magnesian. The mineralogical particularities of kimberlites are related to the behaviour of axides. This is a gradual decrease of picroilmenite content and a relative amount of high-Fe olivine to final stages of intrusion. 
It should be emphasized that on the diagram of a factor analysis with total geochemical data on kimberlites of two pipe bodies of the Udachnaya, the fields of kimberlite varieties are mainly located in a sequence of their intrusion. The kimberlites of initial phases of intrusion, in contrast to final ones, seem to be more rich in Th, Zr, $\mathrm{Nb}$ and $\mathrm{V}$. This regularity of distribution of microadmixtures agrees well with that given above for petrogenic oxides The maximum concentrations of $\mathrm{TiO}_{2}$ and $\mathrm{P}_{2} \mathrm{O}_{5}$ are observed in the pre-pipe veins which accompany most of large pipes. It indicates that the observed trend of variability of kimberlite composition is of general character.

The kimberlite pipes are usually groupped as linear extended chains - clusters of pipes. The tendency for a decrease of $\mathrm{TiO}_{2}$ and $\mathrm{FeO}$ in kimberlites in one direction is evident within linear chains of pipes. The regular change of picroilmenite composition is observed on the limited data (within one chain of pipes of Daldyn field).

Similar to formation of mult1-phase pipes, the formation of linear clusters of pipes is considered as successively forming multi-channel system connected with the common mantle chamber, but isolated spatially within sedimentary cover.

The evolution of kimberlite composition is due to different factors:

1) relatively more intensive interaction of initial phases (versus subsequent one) of kimberlite intrusion with deep-seated rocks of the mantle;

2) thermal-diffusion mechanism of differentiation which is responsible for enrichment of the upper part of the rising magmatic column with easily fusible elements. 